\title{
Altered Serum Levels of Brain-Derived Neurotrophic Factor in Patients with Pathological Gambling
}

\author{
Olga Geisel Roman Banas Rainer Hellweg Christian A. Müller \\ Department of Psychiatry, Campus Charité Mitte, Charité - Universitätsmedizin Berlin, Berlin, Germany
}

\section{Key Words}

Pathological gambling $\cdot$ Brain-derived neurotrophic

factor $\cdot$ Behavioural addiction $\cdot$ Neurotrophins

\begin{abstract}
Background: Brain-derived neurotrophic factor (BDNF) plays important roles in neurotransmitter release and synaptic plasticity and has been hypothesized to be involved in the development and maintenance of addictive disorders. The objective of this study was to investigate alterations of BDNF expression in a non-substance-related addiction, i.e. pathological gambling (PG). Methods: Serum levels of BDNF were assessed in male patients with PG $(n=14)$ and healthy control subjects ( $n=13$ ) carefully matched for sex, age, body mass index, smoking status and urbanicity. Symptoms and severity of PG were measured by the adapted form of the Yale-Brown Obsessive-Compulsive Scale. Results: BDNF serum levels were significantly increased in patients with PG in comparison to healthy control subjects ( $p=0.016)$. There were no significant correlations between BDNF serum levels and severity of PG or clinical and demographic variables. Conclusions: Our results show alterations of BDNF serum levels in patients suffering from a behavioural addiction and suggest that non-substance-related addictions like PG might be associated with neuroendocrinological changes similar to the changes observed in substance-related addictions.

Copyright $\odot 2012$ S. Karger AG, Basel
\end{abstract}

\section{Introduction}

Pathological gambling (PG) is characterized by persistent and repetitive patterns of gambling, often associated with impaired functioning, reduced quality of life, bankruptcy and divorce $[1,2]$. Several lines of clinical evidence suggest common features of PG and substance dependence [3]; however, the disorder is currently categorized in the group of 'Habit and impulse disorders' in ICD-10 [4] and 'Impulsive control disorders not elsewhere classified' in DSM-IV [5] but will be moved to the category 'Substance use and addictive disorders' in DSM-V [6]. Shared characteristics of PG and substance dependence include genetic [7], clinical [8,9] and common neural features, especially alterations of the dopaminergic mesolimbic reward system [10]. This system, containing dopaminergic neurons that project from the ventral tegmental area (VTA) to the nucleus accumbens (NAc) [11], has repeatedly been shown to be dysfunctional in patients with substance-related addictions like alcohol dependence [12-14] and cocaine dependence [15]. Similarly, a study in patients with PG reported reduced activation in the ventral striatum and the ventromedial and ventrolateral prefrontal cortex in the processing of monetary rewards during a gambling paradigm in comparison to healthy controls [16]. Taken together, these findings suggest a possible common pathophysiological mechanism in both PG and substance dependence and thus might substantiate the

\section{KARGER}

Fax +4161306 1234

E-Mail karger@karger.ch

www.karger.com
(C) 2012 S. Karger AG, Basel

1022-6877/12/0186-0297\$38.00/0

Accessible online at:

www.karger.com/ear
Christian A. Müller, MD

Department of Psychiatry, Campus Charité Mitte

Charité - Universitätsmedizin Berlin

Charitéplatz 1, DE-10117 Berlin (Germany)

E-Mail ch.mueller@charite.de 
understanding of PG as a non-substance-related or behavioural addiction.

Brain-derived neurotrophic factor (BDNF), a member of the neurotrophin protein family, represents an important modulator of neurotransmitter release and synaptic plasticity as well as axonal and dendritic morphology [17] and has been hypothesized to be involved in the development and maintenance of addictive disorders [18]. There is preclinical evidence for the involvement of BDNF in trophic support to adult dopaminergic neurons and the regulation of midbrain dopamine release [19]. Regarding drug-related neuroadaptations, it has been suggested that changes in BDNF and its signaling pathways might alter the function of neurons within the VTA-NAc reward circuit to modulate the motivation to consume addictive substances [20-23]. A preclinical study reported reduced cortical BDNF concentrations in mice after chronic alcohol exposure [24]. Furthermore, it has been shown that reduced BDNF expression was associated with increased alcohol-related behaviour in rodents, whereas increased BDNF expression attenuated these behaviours [25]. In alcohol-dependent patients who had abstained from alcohol for at least 30 days, plasma levels of BDNF were found to be decreased in comparison to healthy controls [26]. In contrast, Lee et al. [27] reported increased plasma levels of BDNF in alcohol-dependent patients within $24 \mathrm{~h}$ of abstinence.

Based on these findings in substance-related addictions, we started a pilot study to investigate the role of BDNF in a non-substance-related addiction such as PG. Therefore, we assessed BDNF serum levels in a sample of male patients suffering from PG in comparison to healthy male control subjects.

\section{Subjects and Methods}

\section{Subjects}

A total of 14 male patients with PG (table 1) were recruited from the outpatient unit of the Department of Psychiatry, Campus Charité Mitte, Charité - Universitätsmedizin Berlin, after obtaining written informed consent. The diagnosis of PG was determined by an experienced psychiatrist using a semi-structured interview. All patients fulfilled the diagnostic criteria for PG according to ICD-10 [4] and DSM-IV [5]. Patients suffering from axis I diagnoses other than PG were not included in the study, nor were medicated patients, patients with severe internal or neurological diseases or patients showing positive breath alcohol concentrations.

The control group consisted of 13 healthy male subjects who were screened for psychiatric, neurological and internal disorders using a semi-structured clinical interview performed by an experienced clinician. The samples were carefully matched to prevent
Table 1. Characteristics of patients with PG $(n=14)$ and healthy controls $(n=13)$

\begin{tabular}{|c|c|c|}
\hline & $\begin{array}{l}\text { Patients } \\
\text { with PG }\end{array}$ & $\begin{array}{l}\text { Healthy } \\
\text { controls }\end{array}$ \\
\hline Age, years & $35.4 \pm 9.5$ & $35.2 \pm 8.4$ \\
\hline Males & 14 & 13 \\
\hline \multicolumn{3}{|l|}{ Smoking status } \\
\hline Smokers & 8 & 7 \\
\hline Non-smokers & 6 & 6 \\
\hline Urban dwellers & 14 & 13 \\
\hline Body mass index, $\mathrm{kg} / \mathrm{m}^{2}$ & $27.6 \pm 2.9$ & $26.6 \pm 3.2$ \\
\hline Duration of PG, years & $5.3 \pm 5$ & - \\
\hline Gambling frequency, h/week & $39.5 \pm 27.1$ & - \\
\hline Amount of indebtedness, EUR & $28,210.7 \pm 50,933.1$ & - \\
\hline PG-YBOCS total score & $17.5 \pm 9$ & - \\
\hline PG-YBOCS urges/thoughts score & $7.4 \pm 4.5$ & - \\
\hline PG-YBOCS behaviour score & $9.8 \pm 5.1$ & - \\
\hline \multicolumn{3}{|l|}{ Type of gambling } \\
\hline Slot machines & 12 & - \\
\hline Roulette & 1 & - \\
\hline Sports bets & 1 & - \\
\hline
\end{tabular}

Values represent means \pm SD or numbers of subjects, as appropriate. $\mathrm{p}>0.05$ for all characteristics.

the confounding effects of sex, age, body mass index, smoking status and urbanicity (table 1) [28, 29]. The mean platelet count was in the normal range (150-400/nl) in patients with PG and healthy controls. The study was approved by the local ethics committee and adhered to the Declaration of Helsinki.

\section{Assessments}

All patients were administered the Yale-Brown ObsessiveCompulsive Scale adapted for PG (PG-YBOCS), a valid and reliable measure of the severity of PG [30]. The PG-YBOCS consists of 10 items, each rated on a 5 -point severity scale from 0 to 4 , and a total score ranging from 0 to 40 . The first five questions assess gambling urges and thoughts, the last five assess gambling behaviour.

\section{Measurement of BDNF Serum Levels}

Blood samples were collected between 9.00 and 10.00 a.m. and stored at $18-25^{\circ} \mathrm{C}$ until centrifugation for approximately $30 \mathrm{~min}$. After centrifugation of blood samples at 5,000 rpm for $5 \mathrm{~min}$ at $18-25^{\circ} \mathrm{C}$, serum aliquots were stored at $-70^{\circ} \mathrm{C}$. BDNF serum concentrations were measured in the re-thawed serum samples using improved enzyme-linked immunosorbent assay kits according to the manufacturer's instructions (Promega Inc., Mannheim, Germany) but adapted to the fluorometric technique used also for nerve growth factor determination. For this BDNF assay procedure, a detection limit of $0.7 \mathrm{pg} / \mathrm{ml}$ serum BDNF has been described. For further details, see the report of Ziegenhorn et al. [31]. 


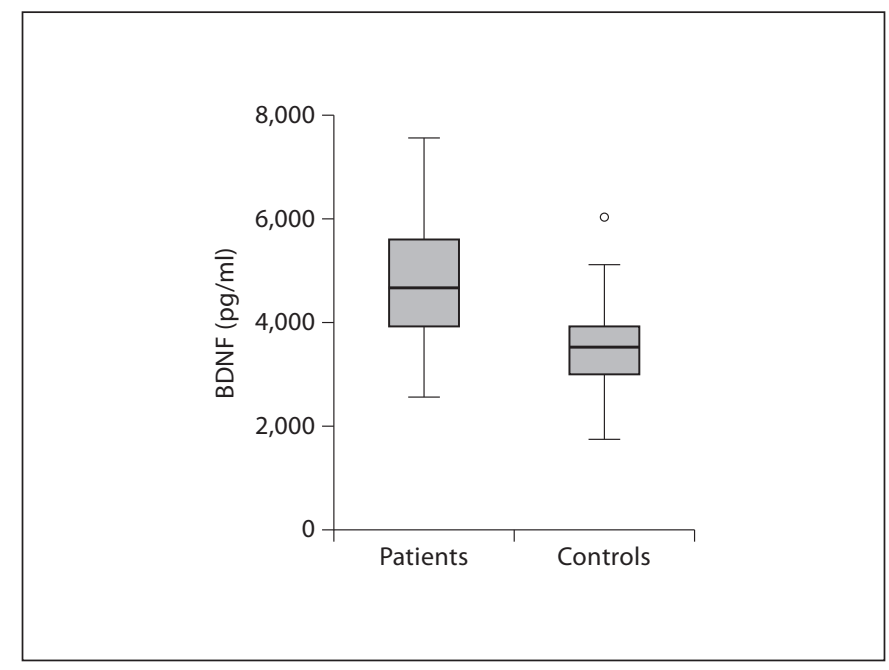

Fig. 1. Boxplots of serum BDNF levels of patients with PG $(n=14)$ and healthy controls $(\mathrm{n}=13) \cdot \mathrm{p}=0.016$.

Statistical Analyses

Results are presented as means \pm standard deviation. The Kolmogorov-Smirnov test was used to evaluate whether BDNF levels were normally distributed. Differences between BDNF serum levels of both groups were calculated using the t-test for independent samples. Correlations between BDNF concentrations and demographic and clinical variables were analysed by Pearson's correlation coefficient. Statistical analyses were performed using IBM SPSS Statistics, version 19 (SPSS Inc., Chicago, Ill., USA).

\section{Results}

Characteristics of the patients with PG and healthy controls are presented in table 1 . There were no significant differences between the groups with regard to age, body mass index, smoking status and urbanicity $(\mathrm{p}>$ 0.05 ). BDNF serum levels were normally distributed according to the Kolmogorov-Smirnov test. Mean BDNF serum levels were significantly increased in the group of patients with PG $(4,762.1 \pm 1,335.2 \mathrm{pg} / \mathrm{ml})$ in comparison to healthy controls $(3,479.6 \pm 1,230.8 \mathrm{pg} / \mathrm{ml} ; \mathrm{p}=$ $0.016)$ (fig. 1). There were no significant correlations of BDNF serum levels with duration of $\mathrm{PG}$, gambling frequency or PG-YBOCS scores $(\mathrm{p}>0.05)$. Also, platelet count, body mass index, age, smoking status and other demographic variables showed no correlation with BDNF serum levels in either group ( $\mathrm{p}>0.05)$.

\section{Discussion}

Several studies have reported alterations of BDNF serum levels in patients suffering from substance-related addictions such as alcohol and opiate dependence $[26,27$, $32]$. In the present study, we found increased serum concentrations of BDNF in a sample of male patients with PG in comparison to individually matched healthy male control subjects. This finding is partially in line with a recent study that also found increased serum levels of BDNF in PG [33]; however, these alterations have only been shown in a subgroup of patients with severe PG, showing no differences between mild-to-moderately affected patients and healthy controls. This discrepancy might possibly be related to different matching procedures used in these studies. Angelucci et al. [33] included healthy controls matched only with regard to age. However, since sex, smoking status and urbanicity have also been identified as confounding factors for BDNF serum levels [28], we carefully matched the control subjects with regard to these variables.

BDNF is able to cross the blood-brain barrier by a high-capacity, saturable transport system [34]. In preclinical studies, cortical BDNF levels have been shown to be positively correlated with serum BDNF levels $[35,36]$. Thus, we hypothesize that our findings of increased BDNF serum levels might reflect increased BDNF levels in the brains of patients with PG. However, the precise relationship between serum BDNF levels and cerebral concentrations of BDNF in humans is still unclear.

Intriguingly, this study indicates changes in BDNF serum levels in patients with PG, a putative behavioural addiction. Together with Angelucci et al. [33], our results suggest that a non-substance-related addiction like PG might be associated with neuroendocrinological changes similar to changes observed in substance-related addictions. Several authors have hypothesized that these alterations represent neuroprotective mechanisms to counteract substance-induced neuronal damage [27,37]. However, in PG one could speculate that increased BDNF levels represent a compensatory mechanism to normalize dopaminergic transmission in the VTA and the NAc, since dysfunctions of the reward system have been shown in PG [16], and BDNF is linked to midbrain dopamine release [19].

Further interpretations of our findings consider the role of BDNF in neuroplasticity and stress-preventive pathways [38-40]. Recently, it has been reported that behavioural stress significantly increased serum levels of BDNF in healthy controls as well as in alcohol-dependent 
patients [41]. Furthermore, BDNF serum levels were reported to be increased in alcohol-dependent patients within the first $24 \mathrm{~h}$ of abstinence [27]. In PG, frequently experienced craving for as well as daily withdrawal of gambling might act as repetitive stress stimuli, thus inducing those stress-preventive and neuroprotective mechanisms.

Previous studies found an association between the Val66Met BDNF gene polymorphism and alcohol dependence $[42,43]$. However, our sample was too small to investigate the role of that polymorphism in PG.

There are several limitations of our study that are due to the pilot character of the study. Although control subjects were carefully matched to the patients to minimize the influence of various confounding factors on BDNF serum levels, such as sex, age, body mass index, smoking status and urbanicity, the sample size of the present study was too small to draw final conclusions. Furthermore, only one single measurement of BDNF serum concentrations was performed; therefore, time course effects in PG on serum levels of BDNF could not be assessed in this study.

In summary, we found that BDNF serum levels were increased in male patients with PG. Similar alterations of BDNF serum levels have been reported in several substance-related addictive disorders. Thus, our study contributes to the understanding of PG as a behavioural addiction. However, the underlying pathophysiological mechanisms need to be elucidated by further preclinical and clinical studies.

\section{Acknowledgements}

We would like to thank our study nurse Olga Vitlif for her dedicated work and Silvia Saft for excellent technical assistance.

\section{Disclosure Statement}

The authors state that there are no conflicts of interest.

\section{References}

1 Grant JE, Kim SW: Quality of life in kleptomania and pathological gambling. Compr Psychiatry 2005;46:34-37.

2 Argo TA, Black DW: Clinical characteristics; in Grant JE, Potenza MN (eds): Pathological Gambling: A Clinical Guide to Treatment. 2004, pp 39-53.

- 3 Frascella J, Potenza MN, Brown LL, Childress AR: Shared brain vulnerabilities open the way for nonsubstance addictions: Carving addiction at a new joint? Ann NY Acad Sci 2010;1187:294-315.

4 Dilling $\mathrm{H}$, Mombour W, Schmidt $\mathrm{MH}$, Schulte-Warkwort E (eds): WHO. Internationale Klassifikation psychischer Störungen. ICD-10 Kapitel V (F) Forschungskriterien. Bern, Huber, 1994.

5 American Psychiatric Association: Diagnostic and Statistical Manual of Mental Disorders (DSM-IV), ed 4. Washington, American Psychiatric Association, 1994.

6 American Psychiatric Association: DSM-V Development. 2011. http://www.dsm5.org/ proposedrevision/Pages/SubstanceUseandAddictiveDisorders.aspx (accessed 26 October 2011)

7 Slutske WS, Eisen S, True WR, Lyons MJ, Goldberg J, Tsuang M: Common genetic vulnerability for pathological gambling and alcohol dependence in men. Arch Gen Psychiatry $2000 ; 57: 666-673$.
8 Tavares $\mathrm{H}$, Zilberman ML, Hodgins DC, el-Guebaly N: Comparison of craving between pathological gamblers and alcoholics. Alcohol Clin Exp Res 2005;29:1427-1431.

-9 Kertzman S, Vainder M, Vishne T, Aizer A, Kotler M, Dannon PN: Speed-accuracy tradeoff in decision-making performance among pathological gamblers. Eur Addict Res 2010;16:23-30.

10 Brewer JA, Potenza MN: The neurobiology and genetics of impulse control disorders: relationships to drug addictions. Biochem Pharmacol 2008;75:63-75.

11 Ikemoto S: Dopamine reward circuitry: two projection systems from the ventral midbrain to the nucleus accumbens-olfactory tubercle complex. Brain Res Rev 2007;56:2778.

12 Wrase J, Schlagenhauf F, Kienast T, Wüstenberg T, Bermpohl F, Kahnt T, Beck A, Ströh le A, Juckel G, Knutson B, Heinz A: Dysfunction of reward processing correlates with alcohol craving in detoxified alcoholics. Neuroimage 2007;35:787-794.

13 Beck A, Schlagenhauf F, Wüstenberg T, Hein J, Kienast T, Kahnt T, Schmack K, Hägele C, Knutson B, Heinz A, Wrase J: Ventral striatal activation during reward anticipation correlates with impulsivity in alcoholics. Biol Psychiatry 2009;66:734-742.
14 Martinez D, Gil R, Slifstein M, Hwang DR, Huang Y, Perez A, Kegeles L, Talbot P, Evans S, Krystal J, Laruelle M, Abi-Dargham A: Alcohol dependence is associated with blunted dopamine transmission in the ventral striatum. Biol Psychiatry 2005;58:779-786.

-15 Asensio S, Romero MJ, Palau C, Sanchez A, Senabre I, Morales JL, Carcelen R, Romero FJ: Altered neural response of the appetitive emotional system in cocaine addiction: an fMRI Study. Addict Biol 2010;15:504-516.

16 Reuter J, Raedler T, Rose M, Hand I, Gläscher J, Büchel C: Pathological gambling is linked to reduced activation of the mesolimbic reward system. Nat Neurosci 2005;8:147-148.

17 Chao MV: Neurotrophins and their receptors: a convergence point for many signalling pathways. Nat Rev Neurosci 2003;4:299-309.

18 Corominas M, Roncero C, Ribases M, Castells X, Casas M: Brain-derived neurotrophic factor and its intracellular signaling pathways in cocaine addiction. Neuropsychobiology 2007;55:2-13.

19 Akaneya Y, Takahashi M, Hatanaka H: Selective acid vulnerability of dopaminergic neurons and its recovery by brain-derived neurotrophic factor. Brain Res 1995;704: 175-183.

20 Bolanos CA, Nestler EJ: Neurotrophic mechanisms in drug addiction. Neuromolecular Med 2004;5:69-83. 
21 Pierce RC, Bari AA: The role of neurotrophic factors in psychostimulant-induced behavioral and neuronal plasticity. Rev Neurosci 2001;12:95-110.

-22 Russo SJ, Mazei-Robison MS, Ables JL, Nestler EJ: Neurotrophic factors and structural plasticity in addiction. Neuropharmacology 2009;56(suppl 1):73-82.

$\checkmark 23 \mathrm{Pu}$ L, Liu QS, Poo MM: BDNF-dependent synaptic sensitization in midbrain dopamine neurons after cocaine withdrawal. Nat Neurosci 2006;9:605-607.

-24 Logrip ML, Janak PH, Ron D: Escalating ethanol intake is associated with altered corticostriatal BDNF expression. J Neurochem 2009;109:1459-1468.

-25 McGough NN, He DY, Logrip ML, Jeanblanc J, Phamluong K, Luong K, Kharazia V, Janak $\mathrm{PH}$, Ron D: RACK1 and brain-derived neurotrophic factor: a homeostatic pathway that regulates alcohol addiction. J Neurosci 2004; 24:10542-10552.

-26 Joe KH, Kim YK, Kim TS, Roh SW, Choi SW, Kim YB, Lee HJ, Kim DJ: Decreased plasma brain-derived neurotrophic factor levels in patients with alcohol dependence. Alcohol Clin Exp Res 2007;31:1833-1838.

$\checkmark 27$ Lee BC, Choi IG, Kim YK, Ham BJ, Yang BH, Roh S, Choi J, Lee JS, Oh DY, Chai YG: Relation between plasma brain-derived neurotrophic factor and nerve growth factor in the male patients with alcohol dependence. Alcohol 2009;43:265-269.

-28 Bus BA, Molendijk ML, Penninx BJ, Buitelaar JK, Kenis G, Prickaerts J, Elzinga BM, Voshaar RC: Determinants of serum brainderived neurotrophic factor. Psychoneuroendocrinology 2011;36:228-239.

-29 Lang UE, Hellweg R, Sander T, Gallinat J: The Met allele of the BDNF Val66Met polymorphism is associated with increased BDNF serum concentrations. Mol Psychiatry 2009; 14:120-122.
30 Pallanti S, DeCaria CM, Grant JE, Urpe M, Hollander E: Reliability and validity of the pathological gambling adaptation of the Yale-Brown Obsessive-Compulsive Scale (PG-YBOCS). J Gambl Stud 2005;21:431443.

31 Ziegenhorn AA, Schulte-Herbrüggen O, Danker-Hopfe $\mathrm{H}$, Malbranc M, Hartung HD, Anders D, Lang UE, Steinhagen-Thiessen E, Schaub RT, Hellweg R: Serum neurotrophins - a study on the time course and influencing factors in a large old age sample. Neurobiol Aging 2007;28:1436-1445.

32 Heberlein A, Dürsteler-MacFarland KM, Lenz B, Frieling H, Grösch M, Bönsch D, Kornhuber J, Wiesbeck GA, Bleich S, Hillemacher T: Serum levels of BDNF are associated with craving in opiate-dependent patients. J Psychopharmacol 2011;25:14801484.

33 Angelucci F, Martinotti G, Gelfo F, Righino E, Conte G, Caltagirone C, Bria P, Ricci V: Enhanced BDNF serum levels in patients with severe pathological gambling. Addict Biol 2011, E-pub ahead of print.

34 Pan W, Banks WA, Fasold MB, Bluth J, Kastin AJ: Transport of brain-derived neurotrophic factor across the blood-brain barrier. Neuropharmacology 1998;37:1553-1561.

35 Karege F, Schwald M, Cisse M: Postnatal developmental profile of brain-derived neurotrophic factor in rat brain and platelets. Neurosci Lett 2002;328:261-264.

36 Sartorius A, Hellweg R, Litzke J, Vogt M, Dormann C, Vollmayr B, Danker-Hopfe H, Gass P: Correlations and discrepancies between serum and brain tissue levels of neurotrophins after electroconvulsive treatment in rats. Pharmacopsychiatry 2009;42:270276.
37 Angelucci F, Ricci V, Martinotti G, Palladino I, Spalletta G, Caltagirone C, Bria P: Ecstasy (MDMA)-addicted subjects show increased serum levels of brain-derived neurotrophic factor, independently from a rise of drug-induced psychotic symptoms. Addict Biol 2010;15:365-367.

38 Knapman A, Heinzmann JM, Hellweg R, Holsboer F, Landgraf R, Touma C: Increased stress reactivity is associated with cognitive deficits and decreased hippocampal brainderived neurotrophic factor in a mouse model of affective disorders. J Psychiatr Res 2010; 44:566-575.

39 Brunoni AR, Lopes M, Fregni F: A systematic review and meta-analysis of clinical studies on major depression and BDNF levels: implications for the role of neuroplasticity in depression. Int J Neuropsychopharmacol 2008;11:1169-1180.

40 Groves JO: Is it time to reassess the BDNF hypothesis of depression? Mol Psychiatry 2007;12:1079-1088.

41 Meng D, Wu T, Rao U, North CS, Xiao H, Javors MA, Adinoff B: Serum NPY and BNDF response to a behavioral stressor in alcohol-dependent and healthy control participants. Psychopharmacology (Berl) 2011; 218:59-67.

42 Matsushita S, Kimura M, Miyakawa T, Yoshino A, Murayama M, Masaki T, Higuchi S: Association study of brain-derived neurotrophic factor gene polymorphism and alcoholism. Alcohol Clin Exp Res 2004;28:16091612.

-43 Wojnar M, Brower KJ, Strobbe S, Ilgen M, Matsumoto H, Nowosad I, Sliwerska E, Burmeister M: Association between Val66Met brain-derived neurotrophic factor (BDNF) gene polymorphism and post-treatment relapse in alcohol dependence. Alcohol Clin Exp Res 2009;33:693-702. 